19 Revue d'histoire du XIXe siècle

Société d'histoire de la révolution de 1848 et des

révolutions du XIXe siècle

$20 / 21 \mid 2000$

Varia

\title{
Sandrine SCIANO-BENNIS, La renaissance de l'idéalisme à la fin du XIXe siècle, Paris, Honoré Champion, 1999, $624 \mathrm{p}$.
}

Nicole Edelman

\section{OpenEdition \\ Journals}

Édition électronique

URL : http://journals.openedition.org/rh19/232

ISSN : 1777-5329

Éditeur

La Société de 1848

Édition imprimée

Date de publication : 1 juin 2000

ISSN : 1265-1354

\section{Référence électronique}

Nicole Edelman, «Sandrine SCIANO-BENNIS, La renaissance de l'idéalisme à la fin du XIXe siècle, Paris, Honoré Champion, 1999, 624 p. », Revue d'histoire du XIXe siècle [En ligne], 20/21 | 2000, mis en ligne le 04 septembre 2008, consulté le 21 septembre 2020. URL : http://journals.openedition.org/rh19/232

Ce document a été généré automatiquement le 21 septembre 2020.

Tous droits réservés 


\title{
Sandrine SCIANO-BENNIS, $L a$
} renaissance de l'idéalisme à la fin du XIXe siècle, Paris, Honoré Champion, $1999,624 \mathrm{p}$.

\author{
Nicole Edelman
}

La Renaissance de l'idéalisme à la fin du XIXe siècle se présente comme un panorama intellectuel et littéraire de la France fin de siècle. Ce livre a pour ambition de "cerner l'univers mental, psychologique et esthétique de toute une génération d'intellectuels ". Sandrine Sciano-Bennis cherche donc à dresser un tableau d'ensemble de ce moment de renaissance de l'idéalisme à la fin du XIXe siècle en France. Pour saisir cette crise des valeurs et des croyances, elle suit et cerne avec une extrême précision, l'enchevêtrement d'idées morales, religieuses, philosophiques et littéraires à travers des œuvres très diverses. La première partie de l'ouvrage évoque à travers de nombreux écrits, ceux de Zola, de Spencer, de Renan, de Taine, de Schopenhauer et d'autres encore, le désenchantement face aux promesses du progrès scientifique. Dans une deuxième partie, l'auteur décrit ce qu'elle appelle "l'aventure intellectuelle " commencée autour d'un retour à la métaphysique. Une troisième et quatrième partie déclinent à travers toute une génération d'écrivains les méandres du développement de l'idéalisme et les questionnements que suscitent le " je " et le " moi ". Enfin, dans une dernier temps, Sandrine Sciano-Bennis tente l'approche de la nébuleuse occultiste des années 1880-1890. Livre-fleuve, l'ouvrage est d'une érudition et d'une densité exceptionnelles mais cette accumulation savante est parfois écrasante. Le lecteur se perd alors au fil d'une écriture qui nous mène d'auteur en auteur, de citation en citation, en un jeu de renvois que l'auteur n'éclaire pas. En effet pour tenter de retrouver la cohérence de ce climat intellectuel de cette fin du XIXe siècle, Sandrine Sciano-Bennis se propose " d'être le témoin impartial et fidèle du regard qu'une époque peut porter sur elle-même". Certitude qui conduit l'auteur à des juxtapositions d'œuvres, là où l'historienne attendrait des interprétations éclairantes qui leur 
donneraient sens.

N.E. 